\title{
Hsp90 Inhibitor HSP990
}

National Cancer Institute

\section{Source}

National Cancer Institute. Hsp90 Inhibitor HSP990. NCI Thesaurus. Code C82387.

An orally bioavailable inhibitor of human heat-shock protein 90 (Hsp90) with potential antineoplastic activity. Hsp90 inhibitor Hsp990 binds to and inhibits the activity of Hsp90, which may result in the proteasomal degradation of oncogenic client proteins, including HER2/ERBB2, and the inhibition of tumor cell proliferation. Hsp90, upregulated in a variety of tumor cells, is a molecular chaperone that plays a key role in the conformational maturation, stability and function of oncogenic signaling proteins, such as HER2/ERBB2, AKT, RAF1, BCR-ABL, and mutated p53, as well as many other molecules that are important in cell cycle regulation and/or immune responses. 